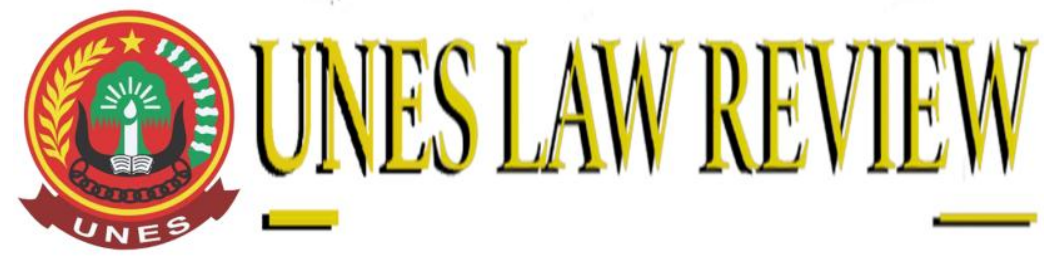

$+6281365118590$ $+6281365118590$

https://review-unes.com/ (9) uneslawreview@gmail.com @ $@$

DOI: https://doi.org/10.31933/unesrev.v3i4

Diterima: 07/07/2021, Diperbaiki: 27/07/2021, Diterbitkan: 01/08/2021

\title{
PERTIMBANGAN HAKIM DALAM MENJATUHKAN PUTUSAN PIDANA BERDASARKAN HASIL SIDANG LAPANGAN (Descente) PADA TINDAK PIDANA KORUPSI \\ (Analisis Putusan Nomor : 15/Pid.Sus-TPK/2019/Pn Jmbi dan Putusan Nomor 60/Pid.Sus-TPK/2017/PN.Mdn.)
}

\section{Dudy Sriyono}

Program Magister Ilmu Hukum, Fakultas Hukum, Universitas Ekasakti, Padang, Indonesia.

Email: dudy_sriyono@yahoo.com

Corresponding Author: Reynaldi Santoso

\section{ABSTRACT}

Field trials or local examinations (descente), there is no normative regulation in the Criminal Procedure Code. Field hearings or local inquiries (descente) are regulated normatively in civil procedural law in Article 153 HIR (Herzeine Inlandsch Reglement). Field hearings (descente) in court proceedings in cases of corruption in the procurement of government goods and services, In case Number 15 / Pid.Sus-TPK / 2019 / Pn Jambi, a field trial was conducted at the location of the object of the case, namely the Tanduk River D.I Irrigation Network, located in Sungai Tanduk Village, Kayu Aro District. Based on the results of the field review by the Panel of Judges, it was evident that the D.I Sungai Tanduk irrigation network was functioning well. The results of the field trial in the judge's decision were used as a consideration for the mitigating circumstances for the defendant. In Decision Number 60 / Pid.Sus-TPK / 2017 / PN.Mdn. a field trial was held in which the Public Prosecutor presented the Auditor and the Legal Counsel for the Defendant to present the Auditor and from the results of the field trial, it was found that state financial losses amounted to IDR 75,522,786.10 (seventy-five million five thousand twenty-two seven hundred eighty-six rupiah ten cents). The judgment of the high court judges regarding the results of the field trials conducted was that the audit results were updated, independent, accepted by both parties and real facts on the ground (real) so that they were used in the verdict. Second, the Power of Evidence Against the Implementation of Field Sessions from these two decisions, it can be seen that field examinations have the same evidentiary power as a trial conducted in a courtroom, namely binding on the judge in making a decision.

Keywords: Judges' Considerations, Criminal Decisions, Field Trials, Corruption 


\begin{abstract}
ABSTRAK
Uji coba lapangan atau pemeriksaan setempat (descente), tidak ada aturan normatif dalam KUHAP. Dengar pendapat atau penyelidikan lokal (descente) diatur secara normatif dalam hukum acara perdata dalam Pasal 153 HIR (Herzeine Inlandsch Reglement). Sidang lapangan (keturunan) dalam persidangan perkara tindak pidana korupsi pengadaan barang dan jasa pemerintah, Dalam perkara Nomor 15/Pid.Sus-TPK/2019/Pn Jambi dilakukan uji coba lapangan di lokasi objek yaitu Jaringan Irigasi DI Sungai Tanduk yang terletak di Desa Sungai Tanduk, Kecamatan Kayu Aro. Berdasarkan hasil peninjauan lapangan oleh Majelis Hakim, terbukti jaringan irigasi D.I Sungai Tanduk berfungsi dengan baik. Hasil sidang lapangan dalam putusan hakim digunakan sebagai pertimbangan untuk hal-hal yang meringankan bagi terdakwa. Dalam Putusan Nomor 60/Pid.Sus-TPK/2017/PN.Mdn. diadakan sidang lapangan dimana Jaksa Penuntut Umum menghadirkan Pemeriksa dan Penasehat Hukum Terdakwa untuk menghadirkan Pemeriksa dan dari hasil uji lapangan tersebut ditemukan kerugian keuangan negara sebesar Rp75.522.786,10 (tujuh puluh lima juta lima ribu dua puluh dua tujuh ratus delapan puluh enam rupiah sepuluh sen). Putusan hakim pengadilan tinggi terhadap hasil uji coba lapangan yang dilakukan adalah hasil pemeriksaan yang diperbaharui, independen, diterima kedua belah pihak dan fakta nyata di lapangan (real) sehingga digunakan dalam putusan. Kedua, Kekuatan Pembuktian Terhadap Pelaksanaan Sidang Lapangan dari kedua putusan tersebut, dapat diketahui bahwa pemeriksaan lapangan memiliki kekuatan pembuktian yang sama dengan persidangan yang dilakukan di ruang sidang, yaitu mengikat hakim dalam mengambil suatu putusan.
\end{abstract}

Kata Kunci: Pertimbangan Hakim, Putusan Pidana, Sidang Lapangan (descente), Korupsi

\title{
PENDAHULUAN
}

Tindak pidana korupsi yang juga dikenal sebagai penyelewengan wewenang demi kepentingan diri sendiri hakikatnya ialah permasalahan keadilan sosial (Purwaning M. Yanuar,2007,37). Suatu elemen krusial dalam teori keadilan sosial ialah tidak boleh melanggar kesejahteraan rakyat, apalagi demi kepentingan pribadi (Marwan Effendy, 2014,79).

Korupsi dianggap sebagai sebuah persoalan yang serius. Karena bisa mengganggu stabilitas serta keamanan rakyat, mengganggu perkembangan ekonomi, sosial, serta politik, dan menghancurkan kaidah-kaidah demokrasi serta integritas, dikarenakan semakin lama tindakan tersebut seperti sudah menjadi hal yang lumrah terjadi. Menurut Mochtar Lubis, korupsi akan muncul jika seseorang tidak mempunyai nilai kebudayaan yang dengan tegas serta akurat membedakan yang menjadi milik pribadi serta masyarakat (I Ktut Sudiharsa,2006,2). Sehingga korupsi bisa mengancam impian masyarakat yang jujur serta sejahtera (Evi Hartanti,2007,1).

Sederhananya, Tindak pidana korupsi bisa dianggap sebagai sebuah kecurangan, yakni mengendapkan uang negara untuk memperuntungkan diri yang bisa membuat negara menjadi rugi (Aziz Syamsudin,2011,15). Tindakan korupsi juga termasuk sebuah kejahatan yang dilaksanakan dengan cermat dan terstruktur, serta dilaksanakan oleh mereka yang memiliki jabatan dan berperan krusial didalam sistem sosial masyarakat. Makanya, perbuatan tersebut juga dinamakan white collar crime yang sifatnya lintas negara. 
Kerugian finansial negara yang tinggi disebabkan tindakan korupsi tersebut menandakan jika sudah terjadi perebutan wewenang-wewenang sosial serta ekonomi rakyat secara luas, sehingga tindakan korupsi tidak bisa dianggap selaku kejahatan biasa namun luar biasa, dan usaha untuk membrantasnya diperlukan usaha dengan metode-metode yang luar biasa serta memakai alat hukum yang luar biasa juga (Elwi Danil, 2011,76).

Dalam KUHAP tidak terdapat aturan yang mengontrol secara normatif terkait pelaksanaan sidang Lapangan atau pemeriksaan setempat (descente) sehingga terjadi kekosongan hukum (recht vacuum), Selama ini dasar hukum Sidang lapangan atau pemeriksaan setempat (descente) hanya diatur secara normatif pada hukum acara perdata Pasal 153 HIR (Herzeine Inlandsch Reglement ). Pasal 153 Ayat (1) HIR menyatakan bahwa "Apabila dianggap wajib ataupun bermanfaat, berarti Ketua bisa menunjuk satu ataupun lebih Komisaris dari Majelis yang didukung Panitera dalam melakukan tinjaun serta pemeriksaan setempat, yang bisa menjadi bahan pertimbangan Hakim".

Contoh konkrit Sidang lapangan (descente) pada proses persidangan perkara Korupsi pengadaan barang dan jasa Pemerintah, terjadi dibeberapa pengadilan Negeri di Indonesia. Kejadian-kejadian ini meliputi, Putusan Pengadilan Nomor: 15/Pid.Sus-TPK/2019/PN Jmb, persoalan Tindak Pidana Korupsi Pengadaan Barang serta Jasa Pemerintah Tahun Anggaran 2016, Pekerjaan Peningkatan Jaringan Irigasi D.I Sungai Tanduk, Kab. Kerinci (Pasal 3 Juncto Pasal 18 ayat (1), (2) serta (3) UU No. 31 tahun 1999 yang sudah dirubah serta ditambahkan dengan UU No. 20 Tahun 2001 Juncto Pasal 55 ayat (1) ke-1 KUHP Juncto Pasal 64 ayat (1) KUHP).

Demikian juga halnya pada Putusan Pengadilan Nomor: 32/Pid.Sus.TPK/2017/PT MDN, perkara Tindak Pidana Korupsi Pengadaan Barang serta Jasa Pemerintah Tahun Anggaran 2015, kegiatan Pembangunan Revitalisasi Terminal Amplas (lanjutan), (Pasal 3 Juncto Pasal 18 UU No. 31 Tahun 1999 Mengenai Pemberantasan Tindak Pidana Korupsi, seperti yang sudah diganti dan ditambahkan dengan UU No. 20 Tahun 2001 Mengenai peralihan terhadap UU No 31 Tahun 1999 Mengenai Pemberantasan Tindak Pidana Korupsi).

Untuk membuktikan tindak pidana pada kasus ini perlu melalui prosedur persidangan penyelidikan biasa di Pengadilan. Prosedur tersebut dibutuhkan oleh hakim, didalam menetapkan tersangka pada kasus ini benar-benar bersalah sesuai dakwaaan oleh Jaksa penuntut umum. Prosedur pembuktian pada kasus tersebut harus sesuai didasarkan pada sistem pembuktian yang ditentukan oleh KUHAP, yakni sistem verifikasi negatif yang dimuat didalam ketetapan Pasal 183 KUHAP. Pasal 183 KUHAP menerangkan jika Hakim didalam menyelidiki, menghakimi dan menetapkan sebuah kasus harus memiliki paling kurang 2 alat bukti valid serta kepercayaan Hakim.

Berdasarkan latar belakang diatas dimana ketidak lazimannya dilakukan sidang lapangan dalam perkara tindak pidana, membuat penulis berkeinginan untuk melakukan riset berjudul "Pertimbangan Hakim Dalam Menjatuhkan Putusan Pidana Berdasarkan Hasil Sidang Lapangan (Descente) Pada Tindak Pidana Korupsi (Analisis Terhadap Putusan Nomor: 15/Pid.Sus-TPK/2019/Pn Jmbi dan Putusan Nomor 60/Pid.Sus-TPK/2017/PN.Mdn.)”. 
Berdasarkan latar belakang tersebut permasalahan yang dibahas adalah:

1. Bagaimana Pertimbangan Hakim terhadap hasil sidang lapangan didalam Putusan Nomor 15/Pid.Sus-TPK/2019/PN Jmbi serta Putusan Nomor 60/Pid.Sus-TPK/2017/PN.Mdn ?

2. Bagaimana kekuatan pembuktian terhadap pelaksanaan sidang lapangan didalam Putusan Nomor 15/Pid.Sus-TPK/2019/PN Jmbi serta Putusan Nomor 60/Pid.SusTPK/2017/PN.Mdn?

\section{METODE PENELITIAN}

Spesifikasi penelitian adalah deskriptif analitis, dengan metode pendekatan yuridis normatife. Riset ini memakai data Priemer, sekunder serta tersier. Data Priemer dari Undang undang dan Yurisprudensi. Data sekunder diperoleh dari buku-buku hukum, artikel hukum yang terdapat di media massa ataupun elektronik. Data Tersier diantaranya ialah berupa sumber yang bisa menunjang bahan hukum primer serta sekunder, contohnya kamus hukum, ekonomi dan ensiklopedia. Data pada Tesis ini didapatkan dari studi kepustakaan, dokumenter, Data yang diperoleh pada hasil riset kemudian dianalisa melalui metode analisis normatif kualitatif.

\section{HASIL DAN PEMBAHASAN}

Putusan Pidana berdasarkan hasil sidang lapangan (descente) dalam kasus tindak pidana korupsi pada putusan Nomor : 15/PID.SUS-TPK/2019/PN JMBI dan Putusan Nomor : 60/PID.SUS-TPK/2017/PN.MDN

\section{Putusan Nomor : 15/Pid.Sus-TPK/2019/Pn Jambi}

\section{a. Kronologi Kasus}

Bahwa ia Terdakwa ITO MUKHTAR Alias PAK AGUNG Bin MUKHTAR, sebagai Direktur PT. Anugerah Bintang Kerinci yang diangkat berdasarkan Keputusan Rapat Umum Pemegang Saham Luar Biasa PT. Anugerah Bintang Kerinci, Nomor : 05 tanggal 15 Juni 2015 oleh notaris Romi Afadarma, SH., M.Kn., baik berbuat secara individual ataupun berdampingan dengan IBNU ZIADY MZ. ST., MH (penuntutan terpisah) selaku Kuasa Pengguna Anggaran Bidang Sumber Daya Air pada Dinas Pekerjaan Umum Provinsi Jambi dan merangkap melaksanakan tugas sebagai pejabat Pembuat Komitmen (PPK) untuk waktu yang tidak dapat ditentukan lagi secara pasti, sekira bulan Maret 2016 yang berlanjut hingga tanggal 29 Desember 2016, atau sekiranya dalam suatu waktu pada tahun 2016, berlokasi di Dinas Pekerjaan Umum Provinsi Jambi dan di Desa Sungai Tanduk Kecamatan Kayu Aro Kabupaten Kerinci Provinsi Jambi atau sekiranya di sebuah lokasi yang masih menjadi wilayah Hukum Pengadilan Tindak Pidana Korupsi pada Pengadilan Negeri Jambi yang berwenang untuk memvalidasi dan menentukan kasus Tindak Pidana Korupsi sesuai dengan Ketetapan Ketua Mahkamah Agung Republik Indonesia No : 153 / KMA / SK / X / 2011 tanggal 11 Oktober 2011, telah melakukan, menyuruh melaksanakan atau ikut serta malaksanakan, berbagai perilaku teradapat kaitannya sehingga perlu dinilai menjadi suatu perilaku berderet yang menantang hukum yaitu: 
1) Bahwa Terdakwa bersama saksi Ir. Boy Edward telah meminta saksi Muhammad Hapis dan saksi Syafrijal untuk membuat dokumen penawaran dalam pelelangan pekerjaan peningkatan jaringan irigasi Daerah Irigasi Sungai Tanduk di Kabupaten Kerinci yaitu dokumen penawaran PT. Anugrah Bintang Kerinci, PT. Izzati Nur Ikhwan dan PT. Air Panas Semurup, namun dalam dokumen - dokumen penawaran yang dibuat oleh saksi Muhammad Hafis dan saksi Syafrijal tersebut, Terdakwa dengan sengaja meminta agar dokumen penawaran milik PT. Izzati Nur Ikhwan dan PT. Air Panas Semurup, persyaratan administrasinya dibuat tidak lengkap dengan tujuan untuk memenangkan PT. Anugrah Bintang Kerinci dalam pelelangan tersebut. Selain itu Terdakwa juga memasukkan persyaratan berupa Sertifikat Keterampilan Kerja (SKT) atau Sertifikat Keahlian Kerja (SKA) tidak sebagaimana dengan sebenarnya.

2) Bahwa Terdakwa telah meminta saksi Ebin Dwisa untuk menandatangani surat perjanjian kerja / kontrak pekerjaan peningkatan jaringan irigasi D.I Sei Tanduk Kabupaten Kerinci tahun anggaran 2016 Nomor : 611/394.a-DPU6.2/IV/2016 tanggal 21 April 2016 untuk nominal perjanjian sejumlah Rp. 7.271.193.000,- (tujuh milyar dua ratus tujuh puluh satu juta seratus sembilan puluh tiga ribu rupiah) bersama dengan saksi Ibnu Ziady MZ. ST., MH selaku Kuasa Pengguna Anggaran (KPA). Selain itu Terdakwa juga meminta saksi Ebin Dwisa untuk membuat, menandatangani dan mengusulkan permohonan pencairan DP kerja $20 \%$ sejumlah sejumlah Rp. 1.454.238.600,- (satu milyar empat ratus lima puluh empat juta dua ratus tiga puluh delapan ribu enam ratus rupiah) kepada saksi Ibnu Ziady.

3) Bahwa Terdakwa tidak melaksanakan kewajibannya sebagai penyedia barang/jasa pekerjaan peningkatan jaringan irigasi D.I Sei Tanduk di Kab. Kerinci TA. 2016, sebagaimana diatur dalam Perka No. 14 Tahun 2012 mengenai Petunjuk Teknis Pengadaan Barang/Jasa Pemerintah Bab III huruf A angka 10, angka 2 huruf u tentang hak dan kewajiban penyedia, yang mana kewajiban tersebut antara lain:

- Memberitahukan pengaplikasian pekerjaan dengan teratur untuk PPK;

- Menjalankan dan menangani pekerjaan berdasarkan agenda pengaplikasian pekerjaan yang sudah ditentukan pada perjanjian;

Bahwa dalam surat perjanjian kerja / kontrak pekerjaan peningkatan jaringan irigasi D.I Sei Tanduk Kabupaten Kerinci tahun anggaran 2016 Nomor: 611/394.a-DPU6.2/IV/2016 tanggal 21 April 2016, pelaksana pekerjaan yaitu Terdakwa selaku Direktur PT. Anugrah Bintang Kerinci diwajibkan melaksanakan pekerjaan sebagaimana tercantum dalam kontrak, namun dalam pelaksanaannya terdapat beberapa item pekerjaan yang tidak sesuai sehingga terjadi kekurangan volume dan pekerjaan beton tidak dilaksanakan sebagaimana spesifikasi mutu beton yang tercantum dalam kontrak, selain itu Terdakwa selaku Direktur PT. Anugerah Bintang Kerinci, tidak pernah membuat dan menandatangani laporan kemajuan pekerjaan antara lain laporan mingguan, bulanan, serta perkembangan pekerjaan namun PT. anugerah Bintang Kerinci. Namun Terdakwa tetap mengajukan permintaan pembayaran untuk pekerjaan tersebut, yang terdiri dari: 
- Mengajukan permintaan pembayaran termin uang muka $20 \%$ senilai Rp. 1.454.238.600,- (satu milyar empat ratus lima puluh empat juta dua ratus tiga puluh delapan ribu enam ratus rupiah) tanggal 9 Mei 2016.

- Mengajukan permintaan pembayaran termin 61,50\% sejumlah Rp. 3.504. 715.026,(tiga milyar lima ratu empat juta tujuh ratus lima belas ribu dua puluh enam rupiah) tanggal 11 Oktober 2016.

- Mengajukan permintaan pembayaran termin 100\% sejumlah Rp. 2.309. 946.374,-, (dua milyar tiga ratus sembilan juta sembilan ratus empat puluh enam ribu tiga ratus tujuh puuh empat rupiah) tanggal ....Desember 2016.

\section{b. Pertimbangan Hakim}

Mempertimbangkan dalam membuat putusan pidana untuk terdakwa, maka harus ditinjau sebelumnya kondisi yang memberi keringanan dan memberatkan terdakwa;

Kondisi yang memberatkan:

Perbuatan Terdakwa tidak membantu Rencana Pemerintah dalam pemberantasan Tindak Pidana Korupsi;

Kondisi yang meringankan;

1) Terdakwa tidak pernah divonis

2) Terdakwa bersikap baik di persidangan;

3) Terdakwa telah menitipkan uang sejumlah kerugian keuangan negara yang dapat dipergunakan dalam perkara ini; -

4) Berdasarkan hasil tinjauan lapangan oleh Majelis Hakim, jaringan irigasi D.I Sungai Tanduk berfungsi dengan baik;

\section{c. Putusan Hakim}

1) Menyatakan Terdakwa ITO MUKHTAR Alias PAK AGUNG Bin MUKHTAR tidak reliabel dengan valid dan dipastikan bersalah melaksanakan perilaku kejahatan seperti yang terdapat pada tuntutan utama;

2) Melepaskan Terdakwa dari tuntutan utama tersebut;

3) Mengatakan Terdakwa ITO MUKHTAR Alias PAK AGUNG Bin MUKHTAR tersebut diatas, reliabel dengan valid dan dipastikan bersalah melaksanakan perilaku kejahatan korupsi secara bersama-sama dan berlanjut seperti yang terdapat pada tuntutan Subsider;

4) Memberikan hukuman pidana kepada Terdakwa oleh karena itu dengan pidana kurungan selama 1 (Satu) tahun dan 2 bulan dan ganti rugi sejumlah Rp50.000.000,00 (lima puluh juta rupiah) dengan ketetapan apabila ganti rugi tersebut tidak dilunasi digantikan dengan penjara selama 3 (tiga) bulan;

5) Memberikan hukuman Terdakwa dalam melunasi uang pengganti sebanyak Rp1.040.826.000,00,- , serta jika Terdakwa tidak melunasi uang pengganti selambatlambatnya 1 (satu) bulan setelah dakwaan mempunyai kejelasan hukum pasti, maka asetnya akan ditahan oleh Jaksa dan ditawar dalam menggantikan uang pengganti 
tersebut, dalam hal terdakwa tidak memiliki aset yang cukup dalam melunasi uang pengganti maka dipidana dengan kurungan selama 1 (satu) tahun;

6) Memastikan mengembalikan kelebihan pembayaran uang pengganti tersebut sebanyak Rp35.262.000,00 kepada Terdakwa segera sesudah dakwaan tersebut mempunyai kejelasan hukum pasti;

7) Menetapkan barang bukti berupa:

- Surat Perjanjian Nomor: 611/394.a-DPU-6.2/IV/2016, tanggal 21 April 2016 kegiatan pembangunan/rehabilitasi jaringan irigasi, pekerjaan pembangunan jaringan irigasi Daerah Irigasi Sungai Tanduk, Kabupaten Kerinci, beserta dokumen lampirannya dipergunakan dalam perkara An. Ir. N. HERO PUTRA Bin AMALIK.

\section{Putusan Nomor 60/Pid.Sus-TPK/2017/PN.Mdn.}

\section{a. Kronologi Kasus}

Terdakwa Tiurma Pangaribuan, Bsc bertindak secara berdampingan atau individual dengan Ir. Bukhari Abdullah dan Khairudi Hazfin Siregar, ST., (tiap pendakwaan dilaksanakan dengan tersendiri), diwaktu tertentu antara tahun 2014 hingga tahun 2015, berlokasi di Kantor Dinas Perumahan dan Permukiman Kota Medan J1 Jenderal Besar A.H No.17 Pangkalan Mansyur Medan atau sekurang-kurangnya dalam sebuah lokasi yang sesuai dengan Pasal 5 UU No. 46 Tahun 2009 mengenai Peradilan Tindak Pidana Korupsi dan Pasal 3 Angka 1 Keputusan Ketua Mahkamah Agung Republik Indonesia No: 022/KMA/SK/II/2011 tanggal 7 Februari 2011, masih berada di bawah yurisdiksi Pengadilan Tindak Pidana Korupsi pada Pengadilan Negeri Medan, yang berotoritas meninjau dan mendakwanya karena ia adalah perseorangan atau yang telah melaksanakan atau berpartisipasi dalam kegiatan mencari keuntungan secara tidak sah yang dapat memberikan kerugian finansial negara atau ekonomi negara, yang dilaksanakan dengan metode berikut:

1) Pada Dokumen pelaksanaan Anggaran Satuan Kerja Perangkat Daerah (DPA-SKPD) TA 2015 Belanja Langsung Nomor : 1.040102.6552 yang disahkan oleh Gunawan Surya Lubis,ST.MM sebagai Kepala Dinas Perumahan dan Permukiman Kota Medan yang disetujui oleh Ir Irwan Ritonga sebagai Pejabat Pengelola keuangan Daerah yang disahkan tangga 20 Oktober 2014 dengan patokan dana sebanyak Rp.6.000.000.000 yang berasal dari APBD Kota Medan pada Dinas Perumahan dan Permukinan Kota Medan untuk Pembangunan Lanjutan Revitalisasi Terminal Amplas TA 2015;

2) Sesuai dengan Surat Kepala Dinas Perumahan dan Permukiman Kota Medan Nomor : 821.5/752/2015 tanggal 15 April 2015 mengenai Penentuan Pimpinan yang diberikan tanggung jawab sebagai pemakai dana/pemakai komoditas tahun 2015 sesuai dengan rencana dan aktivitas dalam Dinas Perumahan dan Permukiman Kota Medan TA 2015 yang disahkan oleh Gunawan Surya Lubus, ST.MM adalah KHAIRUDI Hazfin Siregar, ST serta sebagai PPK (Pejabat Pembuatn Komitmen) dalam aktivitas Pembangunan Revitalisasi Terminal Amplas (lanjutan) tahun 2015;

3) Sesuai dengan surat Keputusan Kuasa Pengguna Anggaran Nomor : 821.5/162/2015 tanggal 6 Pebruari 2015 mengenai Penetapan Pejabat Pelaksana Teknis Kegiatan (PPTK) 
Rencana Pengembangan Sarana dan Prasarana Aparatur, Rencana Pengembangan Permukiman, Rencana Lingkungan Sehat Permukiman, Rencana Penyedian Pengembangan dan Perbaikan sarana dan Prasarana Puskesmas/Puskesmas Pembantu dan Jaringannya dan Rencana Pengaplikasian Aktivitas Keagamaan dan Hari-hari besar TA 2015 pada wilayah Dinas Perumahan dan permukiman Kota Medan yaitu Dedy D.P Hutabarat;

4) Sesuai dengan surat dari Kepala Dinas Perumahan dan Permukiman Kota Medan Nomor: 910/1330 tanggal 14 Agustus 2015 yang diajukan untuk Kepala Unit Layanan Pengadaan (ULP) Kota Medan Bagian Perlengkapan dan Aset Setda Kota Medan menginstruksikan pada pengadaan penjualan fasilitor produk/layanan pemerintah pada Dinas Perumahan dan Permukiman Kota Medan APBD TA 2015 dengan menyertakan berkas-berkas, yaitu:
a) HPS;
b) Gambar Shop Drawing;
c) Rincian teknis produk/layanan;
d) Konsep perjanjian;
e) Kerangka Acuan Kerja (KAK);
f) Dokumen Pelaksana Anggaran (DPA);
g) Sistem Informasi Rencana Umum Pengadaan (SIRUP);

5) Pembuatan HPS, Gambar Shop Drawing, Rincian teknis produk/layanan, konsep perjanjian serta Kerangka Acuan Kerja (KAK) adalah KHAIRUDI HAZFIN SIREGAR, ST., sebagai KPA dan sebagai PPK, sementara dokumen Pelaksana Anggaran (DPA) dan Sistem Informasi Rencana Umum Pengadaan (SIRUP) yang membentuk ialah Kasubbag Perencanaan untuk bagian sekretariat, terdapat juga Kerangka Acuan Kerja yang dibentuk sesuai dengan RAB dan KAK mencakup:
a) Tempat;
b) Sumber anggaran;
c) Cakupan proyek;
d) Bentuk perjanjian;
e) Karakteristik;
f) Perlengkapan dasar;

6) Dalam melanjutkan proyek Pembangunan Lanjutan Revitalisasi Terminal Amplas TA 2015 Wakil Kepala Unit layanan Pengadaan Kota Medan Ir FADLI membentuk Kelompok Kerja (POKJA) Revitalisasi Terminal Amplas (Lanjutan) pada Dinas Perumahan dan Permukiman Kota medan TA 2015 sesuai dengan Surat Keputusan Wakil Kepala Unit layanan Pengadaan Kota Medan Nomor: 554/SK/POKJA.ULP/VIII/2015 tanggal 20 Agustus 2015 dengan struktur berikut :
a) Hardy Patuan H Sibarani, ST.MM ketua;
b) Doni Edwin Siregar Sekretaris;
c) Syaiful Amri, S.Sos Anggota;
d) Ahmad Buhari Siregar, ST Anggota; 
e) Legayanti Situmorang, SE Anggota;

Kemudian Hardy Patuan H Sibarani, ST.MM sebagai Ketua Pokja mengadakan perundingan Pokja untuk aktivitas Revitalisasi Terminal Amplas (Lanjutan) tahun 2015 seperti yang terdapat pada surat undangan rapat Nomor: 01/PAKET1/DISPERKIM/POKJA-ULP/VIII/2015 tanggal 25 agustus 2015 yang dilakukan di kantor ULP Kota Medan tanggal 27 Agustus 2015 dan berikut perundingan yang dihasilkan:

1) Mekanisme penawaran dengan memakai setelah ketentuan dengan sistem gugur;

2) Pembentukan Rencana;

3) Pembentukan Berkas Penyediaan;

7) Yang melakukan pendaftaran untuk berpartisipasi pada penawaran terdapat 24 perusahaan tetapi yang mengunggah berkas pelelangan dan ketentuan terdapat 3 perusahaan, yakni:

a) PT Welly Karya Nusantara;

b) PT Tombang;

c) PT Sangsaka;

8) Terdakwa sebagai Dirut PT Welly Karya Nusantara berdasarkan surat Nomor: 0030/SP/PT.WKN/IX/2015 tanggal 01 September 2015 mengusulkan pelelangan Pekerjaan Revitalisasi Terminal Amplas (Lanjutan) untuk POKJA Revitalisasi Terminal Amplas (Lanjutan) dengan menyertakan berkas-berkas Daftar Kuatitas dan Harga.

\section{b. Pertimbangan Hakim}

Pada persidangan kasus korupsi di Pengadilan Negeri Medan dilakukan sidang lapangan pada tanggal 25 Agustus 2017. JPU menghadirkan Auditor dan Penasihat Hukum Terdakwa menghadirkan Auditor. Dari hasil sidang lapangan tersebut ditemukan kerugian keuangan negara berjumlah Rp 75.522.786,10 (tujuh puluh lima juta lima ribu dua puluh dua tujuh ratus delapan puluh enam rupiah sepuluh sen) yang dipakai Penuntut Umum dalam tuntutan pidananya dan selanjutnya menurut perhitungan Majelis Hakim Tindak Pidana Korupsi di Pengadilan Negeri Medan yang didasarkan pada data hasil Audit dari Kantor Akuntan Publik "Tarmizi Achmad" pada tanggal 14 Desember 2016 kerugian keuangan negara adalah berjumlah Rp 340.519.170, 77 (tiga ratus empat puluh juta lima ratus sembilan belas ribu seratus tujuh puluhn rupiah tujuh npuluh tujuh sen) yang harus diganti oleh Terdakwa sebagaimana dalam amar putusannya Nomor 60/Pid.Sus-TPK/2017/PN Mdn tanggal 23 Oktober 2017 diatas.

Namun Majelis Hakim Tindak Pidana Korupsi pada Pengadilan Tinggi Medan tidak sependapat dengan jumlah kerugian keuangan negara sebagaimana perhitungan Majelis Hakim Tindak Pidana Korupsi pada Pengadilan Negeri Medan dalam putusannya No. 60/Pid.Sus-TPK/2017/PN Mdn tanggal 23 Oktober 2017 tersebut, dengan pertimbangan bahwa dari tiga hasil audit yang dilakukan oleh para Auditor yang hasilnya berbeda-beda tersebut, maka hasil audit terahir pada tanggal 25 Agustus 2017 dalam persidangan lapangan Pengadilan Tindak Pidana Korupsi pada Pengadilan Negeri Medan yang dilakukan oleh Auditor Penuntut Umum dan Auditor penasehat hukum terdakwa adalah hasil audit yang ter- 
update, independen, diterima kedua belah pihak dan fakta yang nyata dilapangan (reil) dan jumlah tersebut telah dijadikan jumlah tuntutan uang pengganti kerugian keuangan negara oleh Penuntut Umum dalam tutuntuan pidanannya terhadap Terdakwa berjumlah Rp 75.522.786,10 (tujuh puluh lima juta lima ribu dua puluh dua tujuh ratus delapan puluh enam rupiah sepuluh sen). Sesuai dengan argumen-argumen yang disebutkan, maka Majelis Hakim Tindak Pidana Korupsi pada Pengadilan Tinggi Medan yang menyidangkan kasus tersebut dalam tingkat banding berasumsi bahwa jumlah kerugian keuangan negara yang perlu diganti pihak Terdakwa adalah berjumlah Rp 75.522.786,10 (tujuh puluh lima juta lima ribu dua puluh dua tujuh ratus delapan puluh enam rupiah sepuluh sen).

\section{c. Putusan Hakim}

1) Putusan Nomor 60/Pid.Sus-TPK/2017/PN.Mdn., tanggal 23 Oktober 2017

\section{MENGADILI :}

a) Menyatakan Terdakwa TIURMA PANGARIBUAN, Bsc tidak reliabel dengan valid dan dipastikan bersalah melaksanakan perilaku kejahatan seperti yang terdapat pada tuntutan utama;

b) Melepaskan Terdakwa dari tuntutan utama tersebut;

c) Mengatakan Terdakwa TIURMA PANGARIBUAN, Bsc reliabel dengan valid dan dipastikan bersalah melaksanakan perilaku kejahatan korupsi secara bersama-sama;

d) Memberikan hukuman pidana kepada Terdakwa TIURMA PANGARIBUAN, Bsc untuk pidana kurungan selama 1 (Satu) tahun dan 3 bulan dan ganti rugi sebesar Rp50.000.000,00 (lima puluh juta rupiah) dengan ketetapan apabila ganti rugi tersebut tidak dilunasi digantikan dengan penjara selama 2 (tiga) bulan;

e) Memberikan hukuman tambahan untuk Terdakwa dalam melunasi uang pengganti Rp. 340.519.170,77 (tiga ratus empat puluh juta lima ratus sembilan belas ribu seratus tujuh puluh rupiah koma tujuh puluh tujuh sen), serta jika Terdakwa tidak melunasi uang pengganti dengan durasi 1 (satu) bulan sesudah dakwaan mendapatkan kejelasan hukum pasti, maka asetnya akan ditahan dan ditawar dalam menggantikan uang pengganti tersebut, apabila terdakwa tidak memiliki aset yang cukup dalam melunasi uang pengganti maka dipidana dengan kurungan selama 1 (satu) tahun;

f) Menentukan uang yang terdapat pada bukti setoran Bank Rakyat Indonesia tanggal 19 Desember 2016, Pengirim PT. Bank Rakyat Indonesia.

2) Putusan Nomor 32/Pid.Sus.TPK/2017/PT MDN.

MENGADILI :

a) Menyetujui permohonan banding dari Pengacara Terdakwa tersebut;

b) Mengganti dakwaan Pengadilan Tindak Pidana Korupsi pada Pengadilan Negeri Medan Nomor: 60/Pid.Sus-TPK/2017/PN.Mdn tanggal 23 Oktober 2017 yang dimintai pengajuan banding hanya terkait durasi hukuman yang diberikan dan besaran uang pengganti yang merugikan finansial negara sehingga advokasi rinciannya, yaitu: 
1) Mengungkapkan Terdakwa Tiurma Pangaribuan tidak reliabel dengan valid dan dipastikan bersalah melaksanakan perilaku kejahatan seperti yang terdapat pada tuntutan utama;

2) Melepaskan Terdakwa diatas dari tuntutan utama tersebut;

3) Mengungkapkan Terdakwa Tiurma Pangaribuan, Bsc., telah terbukti seMembebaskan Terdakwa diatas dari tuntutan utama;

4) Mengungkapkan Terdakwa Tiurma Pangaribuan, Bsc., reliabel dengan valid dan dipastikan bersalah melaksanakan perilaku kejahatan korupsi seperti yang terdapat pada tuntutan Subsider;

5) Memberikan hukuman pidana untuk Terdakwa dengan pidana kurungan selama 1 (satu) tahun dan ganti rugi sebesar Rp.50.000.000,- (lima puluh juta rupiah) dengan ketentuan jika ganti rugi tidak dilunasi harus digantikan dengan pidana penjara selama 2(dua) bulan;

6) Menghukum Terdakwa Turma Pangaribuan, BSc. membayar uang pengganti sebesar Rp 75.522.786,10 (tujuh puluh lima juta lima ratus dua puluh dua ribu tujuh ratus delapan puluh enama rupiah sepuluh sen), apabila Terdakwa tidak melunasi uang pengganti seperti yang disebutkan diatas selambat-lambatnya 1 (satu) bulan sesudah dakwaan mendapatkan kejelasan hukum pasti, maka asetnya akan ditahan dan ditawar dalam menggantikan uang pengganti tersebut, apabila terdakwa tidak memiliki aset yang cukup dalam melunasi uang pengganti maka dipidana dengan kurungan selama 1 (satu) tahun.

\section{Pembahasan dan Analisis Pertimbangan Hakim terhadap hasil Sidang Lapangan dalam Putusan Tindak Pidana Korupsi}

\section{Pertimbangan Hakim terhadap hasil sidang lapangan dalam Putusan Nomor 15/Pid.Sus-} TPK/2019/Pn Jmbi dan Putusan Nomor 60/Pid.Sus-TPK/2017/PN.Mdn.

Kewenangan peninjauan lokal tidak menjadi alat bukti, tetapi penyidikan sekitar menjadi unsur dalam memperkuat kepercayaan hakim untuk menetapakan benda sebuah kasus. Pemeriksaan sidang lapangan biasanya dilakukan pada pemeriksaan perkara perdata. Hal tersebut sesuai dengan Pasal 1866 KUH Perdata dan Pasal 284 RBg, tidak diterangkan pada Pasal tersebut terkait peninjauan lokal menjadi alat bukti. Sudikno Mertokusumo menjelaskan, walaupun penyidikan sekitar tidak terdapat pada Pasal 164 HIR, Pasal 184 RBg serta Pasal 1866 KUH Perdata selaku alat bukti, namun dikarenakan sasaran peninjauan lokal untuk Hakim mendapatkan petunjuk yang detail terkait kejadian yang menjadi persoalan, maka kegunaan penyidikan sekitar pada dasarnya yaitu menjadi alat bukti terkait kekuatan pembuktian yang diberikan untuk dijadikan peninjauan hakim. (Sudikno Mertokusumo, 2009,187-188.)

Terlepas dari apakah peninjauan kembali menjadi alat bukti, tidak ada konsensus di antara para ahli, tetapi pelaksanaan peninjauan lokal sering disaksikan oleh publik, yang akan memberikan anggapan positif kepada masyarakat bahwa pengadilan sungguh-sungguh 
memeriksa kasus tersebut seobjektif mungkin sesuai dengan hukum yang berjalan. Sehingga, meskipun peradilan formal tidak dijadikan selaku alat bukti, hasil peninjauan lokal bisa dibuat selaku alat bukti pendukung di pengadilan. Maka, peninjauan lokal yang dihasilkan pada dasarnya adalah kebenaran yang dipastikan selama persidangan di pengadilan, yang mengikat terhadap putusan hakim. Namun sifat kekuatan mengikat itu tidak pasti, dikarenakan hakim dapat dengan independen menetapkan nilai kekuatan pembuktian, serta dengan peninjauan lokal bisa diperjelas dengan adanya variabel nilai kekuatan terikatnya peninjauan lokal pada dakwaan pengadilan.

Peninjaun lokal merupakan peninjauan atau persidangan yang dilaksanakan oleh hakim/majelis hakim pada lokasi kejadian atau perbuatan pidana dilakukan. Hakim/majelis hakim mendatangi lokasi kejadian (umumnya tanah) tersebut untuk mengamati dengan langsung kondisi kejadiaan. Nilai signifikan peninjauan lokal bukan hanya dinilai dari hasil yang digunakan sebagai sesuatu yang dipertimbangkan dalam dakwaan, tetapi berkedudukan utama untuk bermacam unsur dan langkah persidangan. Pada pemeriksaan perkara tindak pidana korupsi keikutsertaan Majelis ke lokasi untuk mengamati kejadian perkara yang memberikan pesan dan penilaian bagi publik. Bahwa negara untuk kejadian tersebut yang diwakili pihak dari badan peradilan yang dengan benar-benar menangani perkara tindak pidana korupsi sebagai media dalam penyelesaian perkara dalam proses penegakan kepastian hukum. Jika kegiatan tersebut dilakukan dengan wawasan dan keinginan besar yang diikuti dengan keyakinan dan ketulusan.

Pelaksanaan pada persidangan menunjukkan signifikansi kegiatan peninjauan lokal terhadap pertimbangan hakim dalam memutuskan perkara tersebut. Pada pemeriksaan setempat untuk perkara Nomor Pengadilan Nomor 15/Pid.Sus-TPK/2019/Pn Jambi serta Putusan Nomor 60/Pid.Sus-TPK/2017/PN.Mdn adalah untuk memperjelaskan tentang unsur kerugian negara yang timbul akibat dari perbuatan tersebut. Peninjauan lokal yang dihasilkan digunakan sebagai dasar penentuan untuk Hakim dalam memutuskan suatu perkara tentang terpenuhi atau tidaknya sesuatu unsur yang didakwakan untuk terdakwa.

Pada perkara Nomor 15/Pid.Sus-TPK/2019/Pn Jmbi salah satu unsur kesalahan terdakwa berdasarkan hasil pemeriksaan Ahli dari Lembaga Pengembangan Jasa Konstruksi Propinsi Sumatera Barat terhadap pekerjaan pemaksimalan jaringan irigasi D.I Sungai Tanduk tersebut adalah terdapat item item pekerjaan yang dikerjakan tidak berdasarkan yang terdapat pada perjanjian sehingga terjadi kekurangan volume fisik pekerjaan, selain itu berdasarkan hasil pemeriksaan Ahli dari UPTD Laboratorium Teknik Dinas Pekerjaan Umum Kab. Kerinci ditemukan adanya pekerjaan beton tidak dilaksanakan sebagaimana spesifikasi mutu beton dalam kontrak. Pertimbangan bahwa perbuatan Terdakwa selaku Direktur Anugrah Bintang Kerinci sebagai pelaksana pekerjaan peningkatan jaringan irigasi D.I Sungai Tanduk Tahun Anggaran 2016 yang tidak menjalankan tanggung jawab dan keharusannya secara benar, yang mengakibatkan terjadinya kehilangan kapasitas fisik proyek dan mutu beton yang tidak sama dengan detail mutu beton dalam kontrak sedangkan Terdakwa telah menerima seluruh uang pembayaran pekerjaan peningkatan Jaringan Irigasi D.I Sungai Tanduk sejumlah 
Rp7.268.900.000,- dan memperoleh keuntungan sebanyak Rp 200.000.000,00 maka menurut Majelis Hakim sudah sesuai dengan aspek memberi keuntungan pribadi, orang lain, ataupun sebuah koorporasi; perkara Pengadilan Nomor 15/Pid.Sus-TPK/2019/Pn Jambi. Berdasarkan pembuktian tersebut maka atas permintaan Penasihat Hukum Terdakwa kepada majelis hakim agar Mejelis Hakim melihat langsung pekerjaan dan hasil pekerjaan tersebut sehingga menjadi suatu pertimbangan yang meringankan bagi Terdakwa.

Permintaan penasehat hukum tersebut dipenuhi oleh Majelis Hakim. Kemudian dilakukan pemeriksaan sidang lapangan di lokasi objek perkara yaitu di Jaringan Irigasi D.I Sungai Tanduk yang terletak di Desa Sungai Tanduk, Kecamatan Kayu Aro. Majelis Hakim telah melihat langsung keadaan hasil pekerjaan Pemaksimalan Jaringan Irigasi D.I Sungai Tanduk yang terletak di Desa Sungai Tanduk, Kecamatan Kayu Aro, yang hasil selengkapnya termuat dalam Berita Acara Persidangan. Berdasarkan hasil tinjauan lapangan oleh Majelis Hakim terbukti bahwa jaringan irigasi D.I Sungai Tanduk berfungsi dengan baik. Hasil sidang lapangan tersebut dalam putusan hakim dijadikan sebagai pertimbangan keadaan yang meringankan bagi terdakwa.

Asas ini masih didasarkan pada penilaian bebas hakim, karena tolok ukur yang dipakai belum tentu atau harus digunakan dasar peninjauan, namun masih bisa digunakan sebagai dasar peninjauan oleh hakim. Hal tersebut terlihat pada keputusan Nomor 60/Pid.SusTPK/2017/PN.Mdn yang kemudian diputuskan kembali dengan tingkat banding pada keputusan Nomor 32/Pid.Sus.TPK/2017/PT MDN. bahwa dalam putusan tersebut hakim atau pengadilan tersebut terdapat perbedaan keputusan yaitu dalam hal penetapan jumlah kerugiaan negara yang timbul akibat perbuatan terdakwa.

Majelis Hakim Tindak Pidana Korupsi Tingkat Banding di Pengadilan Tinggi Medan tidak sepemikiran dengan Majelis Hakim Tindak Pidana Korupsi Tingkat Pertama pada Pengadilan Negeri Medan terkait durasi hukuman untuk Terdakwa dan jumlah kehilangan uang negara yang dikorupsi oleh tersangka. Untuk keputusan hukuman kurungan untuk Tersangka dari Majelis Hakim Tindak Pidana Korupsi Tingkat Banding pada Pengadilan Tinggi Medan sangat berat apabila dihubungkan dengan nominal kerugian finasial negara yang dikorupsi oleh Terdakwa dalam perkara ini yang jumlahnya tidak begitu besar yang akan disebutkan dalam pertimbangan selanjutnya. Oleh karena jumlah kerugian keuangan negara yang tidak begitu besar yang dilakukan oleh Terdakwa dalam perkara tindak pidana korupsi ini, jadi Majelis Hakim Tindak Pidana Korupsi Tingkat Banding pada Pengadilan Tinggi Medan beropini telah dirasakan adil apabila terhadap Terdakwa cukup dijatuhkan pidana penjara minimal saja.

Terhadap kerugian keuangan negara dalam perkara ini ada beberapa perhitungan yang dijadikan acuan yaitu diantaranya hasil dari audit yang dilakukan oleh Politeknik Medan oleh Konster Silain,ST.MT serta Tim Penyidik Kejaksaan Tinggi Sumatera Utara pada tanggal 18 Oktober 2016 kerugian keuangan negara berjumlah Rp 491.104.800 yang dipakai oleh Penuntut Umum dalam dakwaannya. Tindak Pidana Korupsi pada Pengadilan Negeri Medan melakukan sidang lapangan pada tanggal 25 Agustus 2017 Penuntut Umum menghadirkan 
Auditor dan Penasihat Hukum Terdakwa menghadirkan Auditor dan dari hasil sidang lapangan tersebut ditemukan kerugian keuangan negara berjumlah Rp 75.522.786,10 (yang dipakai Penuntut Umum dalam tuntutan pidananya dan selanjutnya menurut perhitungan Majelis Hakim Tindak Pidana Korupsi pada Pengadilan Negeri Medan yang didasarkan pada data hasil Audit dari Kantor Akuntan Publik "Tarmizi Achmad" pada tanggal 14 Desember 2016 kerugian keuangan negara adalah berjumlah Rp 340.519.170, 77 yang harus diganti oleh Terdakwa sebagaimana dalam amar putusannya Nomor 60/Pid.Sus-TPK/2017/PN Mdn tanggal 23 Oktober 2017 diatas. Namun Majelis Hakim Tindak Pidana Korupsi pada Pengadilan Tinggi Medan tidak sependapat dengan jumlah kerugian keuangan negara sebagaimana perhitungan Majelis Hakim Tindak Pidana Korupsi pada Pengadilan Negeri Medan dalam putusannya Nomor 60/Pid.Sus-TPK/2017/PN Mdn tanggal 23 Oktober 2017 tersebut, dengan pertimbangan bahwa dari tiga hasil audit yang dilakukan oleh para Auditor yang hasilnya berbeda-beda tersebut, maka hasil audit terahir pada tanggal 25 Agustus 2017 dalam persidangan lapangan Pengadilan Tindak Pidana Korupsi pada Pengadilan Negeri Medan yang dilakukan oleh Auditor Penuntut umum dan Auditor Pengacra Terdakwa adalah hasil audit yang ter-update, independen, diterima kedua belah pihak dan fakta yang nyata di lapangan (reil) dan jumlah tersebut telah dijadikan jumlah tuntutan uang pengganti kerugian keuangan negara oleh Penuntut Umum dalam tutuntuan pidanannya terhadap Terdakwa berjumlah Rp 75.522.786,10.

Dari argumen-argumen tersebut, jadi Majelis Hakim Tindak Pidana Korupsi pada Pengadilan Tinggi Medan yang menyidangkan kasus tersebut dalam tingkat banding beropini bahwa jumlah kerugian keuangan negara yang perlu diganti Terdakwa adalah berjumlah $\mathrm{Rp}$ 75.522.786,10. Berdasarkan pertimbangan tersebut diatas, maka keputusan Pengadilan Tindak Pidana Korupsi pada Pengadilan Negeri Medan Nomor 60/Pid.Sus-TPK/2017/PN. Mdn., tanggal 23 Oktober 2017 yang diajukan banding tersebut harus diubah hanya terkait durasi hukuman dan besaran kerugian finansial negara yang dilangsungkan Pengadilan Tindak Pidana Korupsi pada Pengadilan Negeri Medan untuk tersangka.

Hasil Sidang lapangan dijadikan pertimbangan dalam menentukan jumlah kerugian negara yang terjadi dan hal tersebut berpengaruh terhadap lamanya pidana yang dijatuhkan. Penghitungan jumlah kerugian negara merupakan dasar menjatuhkan pidana tambahan berupa pengembalian kerugian negara. Dalam hal dalil pembuktian jumlah kerugian negara yang timbul dampak dari perbuatan kejahatan korupsi. Pada putusan nomor dalam putusannya Nomor 60/Pid.Sus-TPK/2017/PN Mdn tanggal 23 Oktober 2017 tersebut, dengan pertimbangan bahwa dari tiga hasil audit yang dilakukan oleh para Auditor yang hasilnya berbeda-beda tersebut, maka hasil audit terahir pada tanggal 25 Agustus 2017 pada persidangan lapangan Pengadilan Tindak Pidana Korupsi pada Pengadilan Negeri Medan yang dilakukan oleh Auditor Penuntut Umum dan Auditor Pengacara Terdakwa adalah hasil audit yang ter-update, independen, diterima kedua belah pihak.

2. Kekuatan Pembuktian Terhadap Pelaksanaan Sidang Lapangan Pada Putusan Nomor 15/Pid.Sus-TPK/2019/Pn Jmbi Dan Putusan Nomor 60/Pid.Sus-TPK/2017/PN.Mdn. 
Dari peradilan formal, penyidikan lapangan yang dihasilkan tidak menjadi alat bukti dikarenkan tidak tercatat selaku alat bukti yang ditetapkan pada Pasal 184 KUHAP, Abdul Kadir Muhammad menjelaskan, kedudukan dari penyidikan lapangan untuk menangani persoalan yang mana dijadikan hakim dalam mendapatkan kejelasan terkait kejadian yang diutarakan sebagai objek sah yang menjadi peninjauan keputusan (Abdul Kadir Muhammad,2012,158). sehingga penyidikan lapangan hanya memiliki nilai kekuatan pembuktian yakni pada alat bukti yang diperiksa pada saat sidang lapangan tersebut. Nilai kekuatan yang terdapat dalam penyidikan lapangan yang dihasilkan, bisa digunakan pertimbangan untuk hakim. Nilai kekuatan yang didapatkan, hanya menjadi pernyataan yang memperjelas mengenai kejelasan yang akurat terkait obyek perkara guna mencukupi aspekaspek dari perilaku kejahatan yang didakwakan.

Apabila digunakan pernyataan yang transparan sebagai dasar peninjauan, artinya pernyataan tersebut pada hakikatnya tidak lebih dari suatu pembuktian mengenai adanya dan kejadian tindak pidana yang sedang diperiksa. Pernyataan itu menjadi hasil yang didapatkan pada penyidikan dan persidangan lokal, yaitu pernyataan yang sesuai dengan kebenaran yang didapatkan pada persidangan, dan hakim harus mempertimbangkannya sebagai dasar pengambilan keputusan. Berkaitan dengan hal tersebut, penyidikan lapangan yang dihasilkan pada hakikatnya adalah kebenaran yang didapatkan di persidangan, yang memiliki kekuatan memaksa untuk pengambilan putusan, namun sifat kekuatan memaksanya tidak bersifat mutlak. Hakim memiliki kebebasan untuk menetapkan nilai kekuatan pembenarannya.

Pemeriksaan lapangan sangat jarang digunakan pada pemeriksaan perkara tindak pidana. Namun pernah digunakan pada pemeriksaan persoalan tindak pidana korupsi. Variabel nilai kekuatannya pada Putusan Hakim adalah variable nilai kekuatan memaksanya pada keputusan persidangan. Pemeriksaan lapangan yang dihasilkan pada perkara Nomor Pengadilan Nomor 15/Pid.Sus-TPK/2019/Pn Jambi serta Putusan Nomor 60/Pid.SusTPK/2017/PN.Mdn.

Pada keputusan Pengadilan Nomor 15/Pid.Sus-TPK/2019/Pn Jambi dimana Terdakwa merasa dirugikan dan tidak mendapatkan keuntungan dalam proyek pekerjaan Peningkatan Jaringan Irigasi Daerah irigasi Sungai Tanduk Tahun Anggaran 2016 di Kabupaten Kerinci, karena Saksi telah menyetorkan atau mengembalikan uang atas permintaan Saksi IBNU ZIADY ke Kas Daerah Provinsi Jambi pada Bank Daerah provinsi Jambi sebanyak Rp1.076.088.000,00, uang pengembalian tersebut Terdakwa dapatkan dengan cara menjual barang atau harta milik Terdakwa, sedangkan dalam pekerjaan tersebut Terdakwa hanya mendapatkan keuntungan sebanyak Rp 200.000.000,00; Bahwa tindakan Terdakwa telah melawan hukum dan berbeda dengan ketentuan ketentuan sebagai berikut :

a. Pasal 1 angka (6) UU No. 18 Tahun 1999 mengenai Jasa Kostruksi, menerangkan : "Ketidak berhasilan bangunan merupakan kondisi dimana bangunan tersebut seluruhnya atau separuh tidak dapat digunakan dan/atau tidak memenuhi ketentuan perjanjian pembangunan atau penggunaannya setelah diserahkan oleh fasilitor layanan dan/atau pemakai layanan." 
b. Pasal 3 angka (1) UU No. 28 tahun 1999 mengenai pelaksanaan Negara yang bersih serta bebas KKN. 3. Pasal 3 PPRI No. 29 Tahun 2000 mengenai pelaksanaan jasa konstruksi, yang menerangkan "Distorsi yang disebabkan oleh kesalahan. Pembangunan gagal dikarenakan status pembangunan tidak memenuhi ketentuan."

Kegagalan proyek menjadi dasar pada penghitungan jumlah kerugian negara. Namun berdasarkan permintaan penasehat hukum terdakwa kemudian dilakukan pemeriksaan lapangan atau sidang lapangan. Majelis Hakim telah melihat langsung keadaan hasil pekerjaan Pemaksimalan Jaringan Irigasi di Sungai Tanduk yang terletak di Desa Sungai Tanduk, Kecamatan Kayu Aro. Hasil dari sidang lapangan ini menyimpulkan bahwa irigasi yang dibuat dapat digunakan dan berfungsi dengan baik.

Sidang lapangan sama halnya dengan pemeriksaan pada persidangan biasa yang dilaksanakan di Pengadilan Negeri. Pada sidang lapangan yang diperiksa adalah merupakan bukti petunjuk yaitu tentang kondisi pekerjaan pembangunan Irigasi tersebut dan kondisinya berfungsi fungsi dibangunnya irigasi. Hasil sidang tersebut menjadi pertimbangan meringankan bagi majelis Hakim dalam memutuskan perkara. Saat dilakukan pemeriksaan lapangan oleh Majelis Hakim, terbukti bahwa jaringan irigasi Daerah irigasi Sungai Tanduk berfungsi dengan baik.

Pada Keputusan No. 32/Pid.Sus.TPK/2017/PT MDN dimana tersangka sudah dipersalahkan melaksanakan tindak pidana korupsi serta dijatuhi pidana berdasarkan Putusan Pengadilan Tindak Pidana korupsi pada Putusan Pengadilan Negeri Medan Nomor 60/Pid.Sus.TPK/2017/PN.Mdn tanggal 23 Oktober 2017 yang salah satu amarnya adalah hukuman bagi Terdakwa untuk membayar uang pengganti sejumlah Rp. 340.519.170, dengan penetapan jika Terdakwa tidak melunasi uang pengganti tersebut selambat-lambatnya 1 (satu) bulan sesudah dakwaan mendapatkan kejelasan hukum pasti, artinya asetnya akan ditahan dan ditawar dalam menggantikan uang tebusan itu, apabila tersangka tidak memiliki aset dalam melunasi uang tebusan, jadi divonis dengan kurungan selama 1 (satu) tahun.

Jumlah kerugian keuangan negara dalam perkara ini ada beberapa beberapa perhitungan yang dijadikan acuan yaitu diantaranya hasil dari audit yang dilakukan oleh Politeknik Medan Konster Silain,ST.MT dan Tim Penyidik Kejaksaan Tinggi Sumatera Utara pada tanggal 18 Oktober 2016 kerugian keuangan negara berjumlah Rp 491.104 .800 yang dipakai oleh Penuntut Umum dalam dakwaannya.

Guna melakukan kembali penhitungan kerugian negara tersebut kemudian dalam persidangan Pengadilan Tindak Pidana Korupsi pada Pengadilan Negeri Medan dilakukan sidang lapangan tanggal 25 Agustus 2017. Pada sidang lapangan ini Penuntut Umum menghadirkan Auditor dan Penasihat Hukum Terdakwa menghadirkan Auditor dan dari hasil sidang lapangan tersebut ditemukan kerugian keuangan negara berjumlah Rp 75.522.786,10 yang dipakai Penuntut Umum dalam tuntutan pidananya. Pembuktian yang dilakukan pada sidang lapangan ini adalah pembuktian terhadap nilai kerugian negara. Alat bukti yang dikemukakan pada persidangan lapangan merupakan alat bukti keterangan ahli. Ahli yang 
dihadirkan adalah ahli keuangan atau auditor guna memberikan pendapat tentang jumlah kerugian negara yang timbul sebagai dampak dari perilaku kejahatan tersebut.

Menurut perhitungan Majelis Hakim Tindak Pidana Korupsi pada Pengadilan Negeri Medan yang didasarkan dari data hasil Audit dari Kantor Akuntan Publik "Tarmizi Achmad" pada tanggal 14 Desember 2016 kerugian keuangan negara adalah berjumlah Rp 340.519.170, 77 yang harus diganti oleh Terdakwa sebagaimana dalam amar putusannya Nomor 60/Pid.Sus-TPK/2017/PN Mdn tanggal 23 Oktober 2017 diatas.

Namun Majelis Hakim Tindak Pidana Korupsi pada Pengadilan Tinggi Medan tidak sependapat dengan jumlah kerugian keuangan negara sebagaimana perhitungan Majelis Hakim Tindak Pidana Korupsi pada Pengadilan Negeri Medan dalam putusannya Nomor 60/Pid.Sus-TPK/2017/PN Mdn tanggal 23 Oktober 2017 tersebut, dengan pertimbangan bahwa dari tiga hasil audit yang dilakukan oleh para Auditor yang hasilnya berbeda-beda tersebut, maka hasil audit terahir pada tanggal 25 Agustus 2017 didalam persidangan lapangan yang dilakukan oleh Auditor PU dan Auditor Pengacara Terdakwa pada Pengadilan Negeri Medan adalah hasil audit yang ter-update, independen, diterima kedua belah pihak dan fakta yang nyata dilapangan ( $r e i l$ ) dan jumlah tersebut telah dijadikan jumlah tuntutan uang pengganti kerugian keuangan negara oleh Penuntut Umum dalam tutuntuan pidanannya terhadap Terdakwa berjumlah Rp 75.522.786,10. Berdasarkan alasan-alasan tersebut, artinya Majelis Hakim Tindak Pidana Korupsi pada Pengadilan Tinggi Medan mengklaim bahwa total kerugian keuangan negara yang harus diganti oleh Terdakwa adalah berjumlah Rp 75.522.786, 10 .

\section{PENUTUP}

Pertimbangan Hakim terhadap hasil sidang lapangan pada Putusan Nomor 15/Pid.SusTPK/2019/Pn Jmbi dan Putusan Nomor 60/Pid.Sus-TPK/2017/PN.Mdn. merupakan dasar pertimbangan Hakim pada penetapan sebuah kasus tentang terpenuhi atau tidaknya sesuatu unsur yang didakwakan kepada terdakwa. Pada putusan Nomor 15/Pid.Sus-TPK/2019/Pn Jambi dilakukan pemeriksaan sidang lapangan di lokasi objek perkara yaitu di Jaringan Irigasi DI Sungai Tanduk yang terletak di Desa Sungai Tanduk, Kecamatan Kayu Aro. Berdasarkan hasil tinjauan lapangan oleh Majelis Hakim terbukti bahwa jaringan irigasi D.I Sungai Tanduk berfungsi dengan baik. Hasil sidang lapangan tersebut dalam putusan hakim dijadikan sebagai pertimbangan keadaan yang meringankan bagi terdakwa. Pada Putusan Nomor 60/Pid.SusTPK/2017/PN.Mdn. dilakukan sidang lapangan dimana Penuntut Umum menghadirkan Auditor dan Penasihat Hukum Terdakwa menghadirkan Auditor dan dari hasil sidang lapangan tersebut ditemukan kerugian keuangan negara berjumlah $\mathrm{Rp} 75.522 .786,10$. Pertimbangan Hakim pengadilan tinggi terhadap hasil persidangan lapangan yang dilakukan adalah bahwa hasil audit tersebut merupakan yang ter-update, independen, diterima kedua belah pihak dan fakta yang nyata di lapangan (reil) sehingga digunakan pada putusan.

Kekuatan Pembuktian Terhadap Pelaksanaan Sidang Lapangan Pada Putusan Nomor 15/Pid.Sus-TPK/2019/Pn Jmbi serta pada Putusan Nomor 60/Pid.Sus-TPK/2017/PN.Mdn adalah 
berdasarkan alat bukti yang diperiksa pada sidang lapangan tersebut. Pada Putusan Nomor 15/Pid.Sus-TPK/2019/Pn Jmbi alat bukti yang diperiksa adalah petunjuk dimana Hakim memeriksa kondisi jaringan irigasi D.I Sungai Tanduk ternyata berfungsi dengan baik. Sedangkan pada Putusan Nomor 60/Pid.Sus-TPK/2017/PN.Mdn alat bukti yang diperiksa adalah keterangan ahli dengan hasil pemeriksaan ahli auditor ditemukan besaran kerugian keuangan negara yang nyata dilapangan. Dari kedua putusan ini terlihat bahwa pemeriksaan lapangan mempunyai kekuatan pembuktian yang sama dengan sidang yang dilakukan diruang Pengadilan yaitu mengikat bagi hakim dalam menjatuhkan putusan.

\section{DAFTAR PUSTAKA}

Aziz Syamsudin, Tindak Pidana Khusus, Sinar Grafika, Jakarta, 2011.

Evi Hartanti, Tindak Pidana Korupsi, Edisi Kedua, Sinar Grafika, Jakarta, 2007.

Elwi Danil, Korupsi: Konsep, Tindak Pidana, dan Pemberantasannya, PT Raja Grafindo Persada, Padang, 2011.

I Ktut Sudiharsa, Pengembalian Aset Kejahatan Korupsi, Catatan Seminar Nasional "Sinergi Pemberantasan Korupsi: Peran PPATK dan Tantangan Asset Recovery”, Jakarta. 2006.

Purwaning M. Yanuar, Pengembalian Aset Hasil Korupsi, PT Alumni, Bandung, 2007.

Sudikno Mertokusumo, Penemuan Hukum Sebuah Pengantar, Cahaya Atma Pustaka, Yogyakarta, 2014.

UU No. 1 tahun 1946 tentang KUHP.

UU No. 8 Tahun 1981, tentang KUHAP.

Kitab UU Hukum Perdata.

Herzien Inlandsch Reglement (H.I.R)

UU RI No. 31 Tahun 1999 tentang Pemberantasan Tindak Pidana Korupsi sebagaimana telah diubah dengan Undang-undang RI Nomor 20 Tahun 2001. 